\title{
Residual effect of pre-emergent herbicides on the initial development and biochemical composition of snap bean seedlings
}

\author{
Efeito residual de herbicidas pré-emergentes no desenvolvimento inicial \\ e na composição bioquímica de plântulas de feijão-vagem
}

Felipe Favoretto Furlan ${ }^{1 *}$, Gustavo Henrique Freiria ${ }^{1}$, Douglas Junior Bertoncelli ${ }^{1}$, Mônica Satie Omura ${ }^{1}$, Verônica Pellizzaro ${ }^{1}$, Lucia Sadayo Assari Takahashi ${ }^{2}$

\begin{abstract}
The use of herbicides must be made in a rational way, giving priority to reduce possible adverse effects on subsequent crops. The objective was to evaluate the residual effect of pre-emergent herbicides on growth and initial development as well as the biochemical composition of snap bean seedlings. The experimental design used was the completely randomized, with four replications in factorial scheme 3x4, three snap bean cultivars (Macarrão Favorito, Macarrão Preferido e Macarrão Trepador) and three pre-emergent herbicides, plus a control (without herbicide). Was use the residual doses of pre-emergent herbicides sulfentrazone in $0.3 \mathrm{~g} \mathrm{ha}^{-1}$, diclosulam in the concentrations of $0.126 \mathrm{~g} \mathrm{ha}^{-1}$ and imazethapyr in $0.05 \mathrm{~g} \mathrm{ha}^{-1}$. The work was developed in a seeds analyze laboratory with the purpose of minimizing possible adverse effects of the environment. The seeds were sowing on germitest paper moistened with solutions containing the herbicides, with each respective treatment. The following characteristics were evaluated: germination (GER), germination speed index (GSI), seedling length (SL) and seedling dry mass (SDM) and soluble protein content (PROT) in addition to the enzymatic activity of catalase (CAT), peroxidase (PER) and phenylalanine ammonia-lyase (PAL). The phytometric variables SL, SDM, GER and GSI reduced in the presence of herbicides, and for the levels of PROT and enzymatic activity of CAT, PER and PAL there was observed a variation according to the genotype. The sulfentrazone showed up as the product of higher toxicity, as well as the Macarrão Trepador as the genotype with lower tolerance.
\end{abstract}

Keywords: phytotoxicity, Phaseolus vulgaris L., low doses

Resumo - O uso de herbicidas deve ser feito de forma racional, dando prioridade em evitar possíveis efeitos adversos nas culturas subsequentes. $\mathrm{O}$ objetivo foi avaliar o efeito residual dos herbicidas pré-emergentes no crescimento e no desenvolvimento inicial, bem como a composição bioquímica das plântulas de feijão vagem. O delineamento experimental utilizado foi o completamente ao acaso, com quatro repetições, em esquema fatorial 3x4, três cultivares de feijão-vagem (Macarrão Favorito, Macarrão Preferido e Macarrão Trepador) e três herbicidas pré-emergentes, além de um controle (sem herbicida). Utilizou-se de doses residuais de herbicidas pré-emergentes sulfentrazone $0,3 \mathrm{~g} \mathrm{ha}^{-1}$, diclosulam $0,126 \mathrm{~g} \mathrm{ha}^{-1} \mathrm{e}$ imazethapyr $0,05 \mathrm{~g} \mathrm{ha}^{-1}$. O trabalho foi desenvolvimento em laboratório de análise de sementes com a finalidade de minimizar possíveis efeitos adversos do

Received: March 23, 2017. Accepted: October 19, 2017.

${ }^{1}$ Universidade Estadual de Londrina - UEL, Rodovia Celso Garcia Cid, Pr 445, Km 380, CEP 86057-970, Londrina, PR, Brazil.E-mail: ffavorettofurlan@gmail.com; gustavo-freiria@hotmail.com; dj_bertoncelli@hotmail.com; monica_omura@hotmail.com; veronicapellizzaro@hotmail.com

2 Departamento de Agronomia, Universidade Estadual de Londrina - UEL, Londrina, PR, Brazil.

E-mail: luciasadayo@gmail.com 
meio. As sementes foram semeadas em papel germitest umedecidos com as soluções contendo os herbicidas, respectivas a cada tratamento. Avaliou-se as seguintes características: germinação (GER), índice de velocidade de germinação (GSI), comprimento de plântulas (SL), massa seca de plântulas (SDM) e teor de proteína solúvel (PROT) além da atividade enzimática da catalase (CAT), peroxidase (PER) e fenilalanina amônia-liase (PAL). As variáveis fitométricas SL, SDM, GER e GSI reduziram na presença de herbicidas, já para os teores de PROT e atividade enzimática da CAT, PER e PAL houve variação de acordo com o genótipo. O sulfentrazone mostrou-se como o produto de maior toxicidade, bem como o Macarrão Trepador como o genótipo de menor tolerância.

Palavras-chave: fitotoxidade, Phaseolus vulgaris L., subdoses

\section{Introduction}

The snap bean (Phaseolus vulgaris L.) is one of the highlights vegetables in the national scenario, being a good option of cultivation on family farms that produces this product in the system of rotation, succession and scheduling of crops. The pod has considerable levels of protein, mineral salts and some compounds with antioxidant capacity.

The herbicide's use, which aims to make the productive environment more efficient and profitable, prioritizing rational weed control (Duart et al., 2013). Some of the herbicides available in the market have pre-emergent action, pulverized at the beginning of the culture cycle with the objective to eliminate the weeds that are still in the initial stages of development (Raimondi et al., 2010).

The imazethapyr is a pre-emergent herbicide used on crops such as common beans, rice and soybean. It is classified as a compound with a selective action, controlling growth of weeds through inhibition of acetolactate synthase (ALS) (Yassumoto et al., 2007). This herbicide is characterized by long persistence in soil and show effect in dicotyledonous and monocotyledon, which reduces the number of applications, however, has reported cases of phytointoxication. Pinto et al. (2009) when evaluating the application of a mixture of herbicides (imazethapyr + imazapic) in ryegrass culture in succession to irrigated rice, observed a phytotoxic effect of this mix, resulting in smaller plants, requiring a range of 180 days from the application until the sowing of the next crop, due to the possibility of this effect persist in soil for a long time, depending on the environment.

Belonging to the chemical group of triazolopyrimidine sulfonanilides, also acting over the inhibition of ALS, most of them act on the dicotyledons and present intermediate persistence in the soil. Dan et al. (2010) evaluating the effect of several pre-emergent herbicides (including diclosulam at the dosage of $35 \mathrm{~g} \mathrm{ha}^{-1}$ ) on weed control in soybean crop and the subsequent effect on successor crop (sorghum), observed that these class of herbicides showed high persistence in soil (diclosulam up to 87 days) and can cause injuries in subsequent crops.

The sulfentrazone is a protoporphyrinogen oxidase inhibitor (PROTOX) that is the enzyme responsible for the oxidation of protoporphyrinogen into protoporphyrin IX, present in the metabolic pathway of chlorophyll biosynthesis. This herbicide has excellent pre-emergent activity in soil to control of several dicotyledonous and some monocotyledon weeds, being widely used in the control of plants resistant to ALS inhibitors (Blanco et al., 2010). Dan et al. (2010) studying the action of pre-emergent herbicides, verified that the residual activity of sulfentrazone was high, exceeding 200 days, which may cause damage to subsequent crops.

These herbicides cause the death of the plant through the formation of free radicals formed under conditions of oxidative stress and also produced by normal reactions of the electron transport chain. Under severe stress conditions, the production of 
free radicals increases considerably, unleashing a series metabolic events that culminate with the lipid peroxidation, advancing to degradation of membranes and cell death (Andres et al., 2007).

Few studies have been conducted in order to evaluate the pre-emergent herbicides effect on the successor cultures. Therefore, the aim of this work was to evaluate, in laboratory conditions, the residual effect of pre-emergent herbicides on growth and initial development, as well as the biochemical variation in seedlings of three genotypes of snap bean with indeterminate growth pattern.

\section{Material and methods}

The experiment was conducted in the Laboratory of Seeds Analyzes, in completely randomized experimental design, with $3 \times 4$ factorial scheme, with four replicates. The treatments consisted of three cultivars of snap beans with indeterminate growth pattern (type IV): Macarrão Favorito, Macarrão Preferido and Macarrão Trepador; and three pre-emergent herbicides, plus a control solution composed of distilled water. The residual doses were calculated based on the half-life (product degradation in determinate period of time) and the residual effect (based in the half-life was measured the product concentration remade on soil) of each herbicide after soybean cultivation (Table 1).

The snap bean seeds were previously accommodated in a controlled environment for the standardization of the degree of humidity of the lots. After this process, was collected a sample of each genotype for the manufacture of germination rolls (experimental units) with 50 seeds each, in germitest paper moistened with the solution corresponding for each treatment (applied a solution with 2.5 times the mass of the dry paper), arranged in a germinator $\left(25^{\circ} \mathrm{C}\right)$. After nine days, the following variables were evaluated:

\section{Seedling Length (SL)}

Ten seedlings were randomly collected from each replicate. Measurement was performed from the root end until the apex of the each genotype stem, and the results expressed in centimeters.

\section{Seedling Dry Mass (SDM)}

The same seedlings analyzed in the SL evaluation were used. The cotyledons were removed and, after this procedure, the seedlings (roots and aerial part) were wrapping in kraft paper bags and kept in forced air circulation oven at a constant temperature $\left(80^{\circ} \mathrm{C}\right)$, up to constant mass. After cooling, the seedlings were weighed with the aid of an analytical balance and the results were expressed in grams per seedling.

\section{Germination (GER)}

Seeds were distributed on moistened germination paper rolls according to treatment (solution of each herbicide) and kept at $25^{\circ} \mathrm{C}$, in accordance with the rules for seed analysis (Brasil, 2009). The results was expressed as a percentage of normal seedlings (plants with root and aerial part developed).

\section{Germination Speed Index (GSI)}

Was based on the Maguire (1962) methodology, following the equation: $\mathrm{GSI}=(\mathrm{G} 1 / \mathrm{N} 1)+(\mathrm{G} 2 / \mathrm{N} 2)+$ $(\mathrm{G} 3 / \mathrm{N} 3)+\ldots+(\mathrm{Gn} / \mathrm{Nn})$, being G1, G2, G3, ... $\mathrm{Gn}$ the number of computed seedlings in the first,

Table 1. Characterization of pre-emergents herbicides used at the experiment on the snap bean genotypes.

\begin{tabular}{ccccc}
\hline Herbicides & Comertial & Concentration a. i. & Half-life & Residual dose \\
\hline Sulfrentrazone & Boral 50 SC & $500.00 \mathrm{~g} \mathrm{~L}^{-1}$ & 180 days & $0.300 \mathrm{~g} \mathrm{ha}^{-1}$ \\
Diclosulam & Spider $840 \mathrm{WG}$ & $840.00 \mathrm{~g} \mathrm{~kg}^{-1}$ & 67 days & $0.126 \mathrm{~g} \mathrm{ha}^{-1}$ \\
Imazethapyr & Pivot & $100.00 \mathrm{~g} \mathrm{~L}^{-1}$ & 90 days & $0.050 \mathrm{~g} \mathrm{ha}^{-1}$ \\
\hline
\end{tabular}


second, third and last count; and N1, N2, N3,..., $\mathrm{Nn}$ represent the number of days from sowing to the first, second, third and last count.

For the determination of biochemical analysis was prepared a protein extract. This extract was obtained by collecting $0.1 \mathrm{~g}$ of fresh vegetable tissue used in the GSI test, macerated in a pre-cooled container containing $4 \mathrm{~mL}$ of buffer solution of potassium phosphate ( $0.1 \mathrm{M}$ and $\mathrm{pH}$ 7.5), being stored in eppendorf tube and centrifuged at $12,000 \mathrm{rpm}$ at $4^{\circ} \mathrm{C}$ for $15 \mathrm{~min}$. From this extract were evaluated:

\section{Total protein (PROT)}

Determined based on the methodology described by Bradford (1976) and used for the calculation of the remaining variables.

\section{Catalase (CAT)}

Collected in a container $900 \mu \mathrm{L}$ of solution B (buffer solution of potassium phosphate - $0.05 \mathrm{M}$ and $\mathrm{pH} 7.0$, also containing hydrogen peroxide $12.5 \mathrm{mM}$ ), in which $100 \mu \mathrm{L}$ of the protein extract supernatant was added. It was determined the enzyme activity of catalase by absorbance of $240 \mathrm{~nm}$, using the molar extinction coefficient of $36 \mathrm{M}^{-1} \mathrm{~cm}^{-1}$ (Anderson et al., 1995).

\section{Peroxidase (PER)}

Quantified by adding in a container $900 \mu \mathrm{L}$ of the solution $\mathrm{A}(250 \mu \mathrm{L}$ guaiacol $+306 \mu \mathrm{L}$ of hydrogen peroxide, adding a buffer solution of potassium phosphate $(0.01 \mathrm{M}$ and $\mathrm{pH} 6.0$ until the volume of $100 \mathrm{~mL}$ ) and $100 \mu \mathrm{L}$ of protein extract supernatant. The data were measured in a spectrophotometer at $470 \mathrm{~nm}$, and the peroxidase activity determined by the conversion of guaiacol to tetraguaiacol (Lusso and Pascholati, 1999).

\section{Phenylalanine ammonia-lyase (PAL)}

Followed the colorimetric procedure of trans-cinnamic acid released from the substrate phenylalanine, according to the methodology described by Kuhn (2007).

The data were submitted to the tests of normality (Shapiro-Wilk) and homogeneity of variance (Hartley) and, subsequently, to the analysis of variance to $5 \%$ of probability. The averages were compared by Tukey test $(\mathrm{p}<0.05)$ and then was performance the Pearson correlation test with significance established by the T-test of Studant.

\section{Results and discussion}

It has significance in the characteristics evaluated in at least one of the sources of variation (Table 2). The seedlings of length (SL) responded only to herbicides $(\mathrm{H})$, on the other hand, the characteristics germination (GER) and the germination speed index (GSI) varied for herbicides and genotypes (G), and the characteristics seedling dry matter (SDM), protein (PROT), catalase (CAT), peroxidase (PER) and phenylalanine ammonia-lyase (PAL) showed significant response to $\mathrm{HxG}$ interaction.

Table 2. Summary of the analysis of variance with mean squares values for the characteristics seedling lengh (SL), seedling dry mass (SDM), germination (GER), germination seed index (GSI), total protein (PROT), catalase (CAT), peroxidase (PER) and phenylalanine ammonia-lyase (PAL) in function of residual effect of pre-emergent herbicides in different snap bean genotypes.

\begin{tabular}{cccccccccc}
\hline \multirow{2}{*}{ Variation sources } & \multirow{2}{*}{$\mathbf{D} \mathbf{~ F}$} & \multicolumn{10}{c}{ Residual } \\
\cline { 2 - 10 } & & SL & SDM & GER & GSI & PROT & CAT & PER & PAL \\
\hline Herbicides (H) & 3 & $7563.59^{* *}$ & $0.001^{* *}$ & $381.64^{* *}$ & $4.86^{* *}$ & $29.86^{* *}$ & $3.01^{* *}$ & $051^{* *}$ & $0.39^{* *}$ \\
Genotype (G) & 2 & $167.09^{\text {ns }}$ & $0.0001^{* *}$ & $7299.25^{* *}$ & $76.14^{* *}$ & $2.05^{* *}$ & $1.47^{* *}$ & $0.06^{* *}$ & $0.03^{* *}$ \\
$\mathrm{H}^{*} \mathrm{G}$ & 6 & $148.27^{\text {ns }}$ & $0.00002^{*}$ & $44.47^{\text {ns }}$ & $0.43^{\text {ns }}$ & $3.49^{* *}$ & $0.62^{* *}$ & $0.04^{* *}$ & $0.04^{* *}$ \\
Residue & 36 & 91.24 & $8 \mathrm{E}^{-06}$ & 39.86 & 0.26 & 0.07 & 0.01 & 0.0002 & 0.0001 \\
Cof. of Variation (\%) & & 16.97 & 13.58 & 8.35 & 6.99 & 8.89 & 14.16 & 4.28 & 2.87 \\
\hline
\end{tabular}

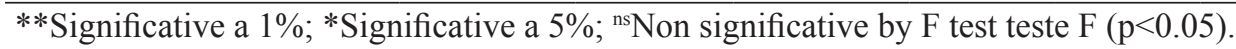


In relation to SL, deleterious effect of herbicides on growth and initial development of seedlings was observed, because, regardless of the genotype, occurred vegetable reduction when compared to the control (Table 3). The herbicide diclusulam provided an average decrease of $44.17 \%$ in length of seedlings when compared with the control treatment, below the values reported for the products imazethapyr and sulfentrazone ( 56.27 and $57.45 \%$, respectively). This phenomenon is related to the deleterious effect caused by the herbicides in the vegetative primordium, which through their action in the action sites generate a reduction in the seedling potential of growth and development, which produces deformed seedlings with low establishment capacity.

The variation presented by SDM followed the same pattern of SL, since the control solution provided higher values of dry mass when compared to herbicides, for all genotypes. In this context, only the cultivar Macarrão Preferido responded differently to each herbicide, because the pre-emergent action of diclosulam produced seedlings with more dry matter than the others, different from the results presented by the genotypes Macarrão Favorito and Trepador (Table 3).

The difference observed can be attributed to the sensitivity of the Macarrão Preferido genotype for each herbicide, since each plant can response with distinct capacity to tolerate different herbicides, due the mechanisms of detoxification and metabolization of molecule. However, regardless of the product and cultivar tested, it was evident that the pre-emergent action reduces the accumulation of dry matter due its performance in the physiological metabolism of seedling growth, either by the influence on the protein metabolic pathway or by the reduction of the assimilation capacity of nutrients. Walperes et al. (2015) studying the action of pre-emergent herbicides, in this case metribuzin, also observed reduction at the dry mass of beans after pre-emergent herbicides, which proves the potential damage of this class of herbicides.
Table 3. Seedling length (SL), seedling dry mass (SDM), germination (GER) and germination speed index (GSI) as function of residual effect of pre-emergent herbicides on snap bean genotypes.

\begin{tabular}{|c|c|c|c|c|}
\hline \multirow{2}{*}{ Herbicides } & \multicolumn{3}{|c|}{ Genotypes } & \multirow[b]{2}{*}{ Mean } \\
\hline & Favorito & Preferido & Trepador & \\
\hline \multicolumn{5}{|c|}{ Seedling lenght (mm) } \\
\hline Control & 85.98 & 87.33 & 105.75 & $93.02 \mathrm{a}$ \\
\hline Sulfentrazone & 40.67 & 37.53 & 40.55 & $39.58 \mathrm{c}$ \\
\hline Diclosulam & 3.58 & & 49.98 & $51.93 \mathrm{~b}$ \\
\hline Imazethapyr & 39.83 & & 43.48 & $40.68 \mathrm{c}$ \\
\hline Mean & 53.76 & 55.2 & 59.94 & \\
\hline \multicolumn{5}{|c|}{ Seedling dry mass (g) } \\
\hline Con & $0.030 \mathrm{aA}$ & $0.030 \mathrm{aA}$ & $0.033 \mathrm{aA}$ & 0.031 \\
\hline Sulfentrazone & $0.020 \mathrm{bA}$ & $0.013 \mathrm{cB}$ & $0.018 \mathrm{bA}$ & 0.017 \\
\hline Diclosulam & $0.020 \mathrm{bA}$ & 0.02 & $0.020 \mathrm{bA}$ & 0.020 \\
\hline Imazethapyr & $0.020 \mathrm{bA}$ & $0.013 \mathrm{cB}$ & $0.020 \mathrm{bA}$ & 0.018 \\
\hline & 0.023 & 0.019 & 0.023 & \\
\hline \multicolumn{5}{|c|}{ Germination (\%) } \\
\hline & 99.00 & 90.00 & 54.0 & $80.50 \mathrm{a}$ \\
\hline Sulfentrazone & 89.00 & 69.0 & 45.00 & $67.67 \mathrm{~b}$ \\
\hline Diclosulam & 94.00 & 81.0 & 54.00 & $75.83 \mathrm{~b}$ \\
\hline Imazethapyr & 95.00 & 83.00 & 57.50 & $78.50 \mathrm{~b}$ \\
\hline & $94.13 \mathrm{~A}$ & $80.50 \mathrm{~B}$ & $52.25 \mathrm{~B}$ & \\
\hline \multicolumn{5}{|c|}{ Germination seepd index } \\
\hline Control & 9.83 & 8.66 & 4.96 & $7.81 \mathrm{a}$ \\
\hline Sulfentrazone & 8.44 & 6.53 & 4.17 & $6.38 \mathrm{~b}$ \\
\hline Diclosulam & 9.18 & 7.57 & 5.10 & $7.28 \mathrm{a}$ \\
\hline Imazethapyr & 9.38 & 8.09 & 5.41 & $7.62 \mathrm{a}$ \\
\hline Mean & $9.21 \mathrm{~A}$ & $7.71 \mathrm{~B}$ & $4.91 \mathrm{C}$ & \\
\hline
\end{tabular}

Means followed by distinct letters differ in line (upper case) and column (lowercase) by Tukey test at $5 \%$ probability.

To characteristic germination it was observed that the control presented higher value (80.50\%) compared to herbicides sulfentrazone, diclosulam and imazethapyr. These herbicides caused reduction in germination process, with inferiority of $15.94,5.80$ and $2.48 \%$ respectively. Mancuso et al. (2016) verified higher phytotoxicity of the herbicide diclosulam in seedlings after nine days of emergency.

The reduction provided by the last two herbicides mentioned may be related to their mechanisms of action, because they have the same site of action, inhibiting the acetolactato Synthase (ALS), 
an enzyme that exerts direct influence on DNA synthesis and cell growth (Yassumoto et al., 2007), which will provoking a deleterious action in the germination mechanism by acting in the process of cell division, thus after contact with the herbicide, a reduction in the formation of healthy seedlings will occur.

In the other hand, the sulfentrazone belongs to the chemical group of protoporphyrinogen oxidase inhibitors (PROTOX), enzyme responsible for the oxidation of the protoporphyrinogen to protoporphine IX. This product is active in biosynthesis of chlorophyll with higher effect when the parts of plant are issued and produces a variety of free radicals when in the presence of light (Oliveira Junior et al., 2011). In this case, the injurious action on germination is attributed to the moment when the seedlings begin the process of chlorophyll synthesis. As previously mentioned, when in the presence of light the pre-emergent herbicide will act, generating a high amount of free radicals, producing deformed seedlings with low survival capacity.

There was variance between the performance of genotypes to GER (Table 3), being that the cultivar Macarrão Favorito presenting the highest average. This discrepancy can be attributed to the oscillation of the physiological quality of seeds among the different samples used in the experiment, because the way the lots are produced can interfere with your ability to express the maximum genetic potential.

Among the several attributes involved in physiological quality of seeds, genetic purity is a highlight characteristic and correlates with factors such as germination and vigor. So the physiological potential of tested genotypes (Table 3 ) was determined by a series of phenomena that occur during cell metabolism which contributed to reduced germination process. This work was conducted under laboratory conditions in order to predict the variations that the use of herbicides tested would in plants under field conditions. Therefore, the sum of these factors reported can determine the performance of the material sown, as well as your establishment.

In this context, the GSI presented a similar behavior to GER due to the fact that the performance of these variables are determined by similar phenomena. In relation to genotypes, the cultivar Macarrão Favorito presented a higher germination speed than the Macarrão Favorito and Trepador, due to the same implications exposed for the variability found in the germination process.

However, as to the effect of herbicides on GSI, only the sulfentrazone behaved differently from the control, with a lower performance in $18.31 \%$ (Table 3). This product provided a lower GSI due to greater impact on the growth of seedlings, causing initial injures at the moment of protrusion of the root primordium, because this product has a systemic and contact action and its absorption is mainly carried out by the root system, with low movement by the phloem (Trevisan et al. 2016). These authors also observed visual symptoms of intoxications in plants after sulfentrazone application, which exemplify a phitotoxic effect on plant growth.

Among the levels of PROT, one of the first biochemical events suffered by the seeds when under some kind of oxidative stress is the damage cause to protein synthesis in the first hour of seed imbibition (Taiz and Zeiger, 2013). In these context, the herbicides diclosulam and imazethapyr produced the lowest protein levels, besides the genotype analyzed (Table 4), because they belong to the group of ALS inhibitors (Oliveira Junior et al., 2011), which is responsible for the formation of essential amino acids and, consequently, proteins.

Another function of this enzyme is to reduce pyruvate in branched chain of amino acids, but when its action inhibited by application of herbicides is an accumulation of pyruvate and phosphoenolpyruvate (pyruvate's precursor), which will be diverted to the route of the chiquimic acid, increasing the activity of the PAL (Taiz and Zeiger, 2013). 
Relating the results obtained for proteins with enzymes, it is observed that in treatments with lower protein content a higher enzymatic activity occurred (Table 4). Therefore, the biochemical and physiological reactions was triggered and caused a deviation of a metabolic route, prioritizing plant defense metabolism in comparison to seedling growth.

In contrast, the herbicide sulfentrazone presented a different response from the others products in relation to protein levels and enzyme activity (Table 4). This fact may be related to sulfentrazone mechanism of action, because this product inhibits the activity of PROTOX, which causes an accumulation of protoporphyrinogen. Then, the protoporphyrinogen diffuses out of the reactive center, occurring a non-enzymatic oxidation. In this scenario, the inhibition of $\mathrm{Mg}$-chelatese on protoporphyrin IX produced by the non-enzymatic pathway occurs, which prevents it from transforming into $\mathrm{Mg}$-protoporphyin IX or has different structural conformation from that produced by the normal pathway (Oliveira Junior et al., 2011). Thus, the interaction between oxygen and light changes the $\mathrm{O}_{2}$ and elevates the singlet state (the most energetic form of this element), being responsible for peroxidation of lipids observed in cell membranes (Zobiole et al., 2007).

Thus, the inhibition of PROTOX by sulfentrazone provides an accumulation of protoporphyrinogen and, consequently its precursor, the glutamate, which is subsequently redirect to the formation of proteins (Taiz and Zeiger 2013).

Therefore, it is believed that the lower enzymatic activity caused by sulfentrazone is related to the higher level of stress caused by this pre-emergent, because the activity of oxidative stress enzymes varies according to the intensity of stress, which when very severe reduces its activity (Pereira et al., 2012).

In relation to the cultivars, it was observed that the genotype Macarrão Preferido presented higher tolerance (besides CAT, which was equal to the cultivar Favorito) to the toxic effects the herbicide sulfentrazone than the other cultivars, because when in contact with the seedling, the activity of the defense enzymes became superior to the control. On the other hand, for the cultivars Macarrão Favorito and Trepador the effect was reversed, because the application of sulfentrazone reduced the activity of enzymes related to oxidative stress. This variation is attributed to the characteristics of the genotype and is explained by the physiological process of seed (germination, dry matter accumulation, etc.),

Table 4. Protein (PROT), catalase (CAT), peroxidase (PER) and phenylalanine ammonia-lyase (PAL) in seedling tissues as a function of the residual effect of pre-emergent herbicides on different snap bean genotypes.

\begin{tabular}{|c|c|c|c|c|}
\hline \multirow{2}{*}{ Herbicides } & \multicolumn{3}{|c|}{ Genotypes } & \multirow[b]{2}{*}{ Mean } \\
\hline & Favorito & Preferido & Trepador & \\
\hline \multicolumn{5}{|c|}{ Protein (mg g ${ }^{-1}$ tissue) } \\
\hline Control & $3.11 \mathrm{bC}$ & $5.56 \mathrm{aA}$ & $4.22 \mathrm{bB}$ & 4.29 \\
\hline Sulfentrazone & $5.02 \mathrm{aA}$ & $3.67 \mathrm{bB}$ & $4.97 \mathrm{aA}$ & 4.55 \\
\hline Diclosulam & $1.40 \mathrm{cB}$ & $1.38 \mathrm{cB}$ & $3.16 \mathrm{cA}$ & 1.98 \\
\hline Imazethapyr & $1.44 \mathrm{cA}$ & $1.50 \mathrm{cA}$ & $1.46 \mathrm{dA}$ & 1.47 \\
\hline Mean & 2.74 & 3.03 & 3.45 & \\
\hline \multicolumn{5}{|c|}{ Catalase $\left(\mathrm{mmol} \mathrm{H}_{2} \mathrm{O}_{2} \mathrm{mg}\right.$ protein $\left.^{-1}\right)$} \\
\hline Control & $0.71 \mathrm{bA}$ & $0.47 \mathrm{cB}$ & $0.61 \mathrm{aAB}$ & 0.60 \\
\hline Sulfentrazone & $0.48 \mathrm{cA}$ & $0.52 \mathrm{cA}$ & $0.24 \mathrm{bB}$ & 0.41 \\
\hline Diclosulam & $2.14 \mathrm{aA}$ & $1.95 \mathrm{aA}$ & $0.57 \mathrm{aB}$ & 1.55 \\
\hline Imazethapyr & $0.90 \mathrm{bB}$ & $1.15 \mathrm{bA}$ & $0.62 \mathrm{aC}$ & 0.89 \\
\hline Mean & 1.06 & 1.02 & 0.51 & \\
\hline \multicolumn{5}{|c|}{ Peroxidase (UABs min-1 mg proten $\left.^{-1}\right)$} \\
\hline Control & $0.23 \mathrm{bA}$ & $0.14 \mathrm{cB}$ & $0.17 \mathrm{cC}$ & 0.18 \\
\hline Sulfentrazone & $0.15 \mathrm{cB}$ & $0.21 \mathrm{bA}$ & $0.15 \mathrm{cB}$ & 0.17 \\
\hline Diclosulam & $0.61 \mathrm{aA}$ & $0.57 \mathrm{aB}$ & $0.25 \mathrm{bC}$ & 0.48 \\
\hline Imazethapyr & $0.61 \mathrm{aA}$ & $0.57 \mathrm{aB}$ & $0.55 \mathrm{aB}$ & 0.58 \\
\hline Mean & 0.39 & 0.37 & 0.28 & \\
\hline \multicolumn{5}{|c|}{$\begin{array}{c}\text { Phenylalanine ammonia-lyase } \\
\left(\text { UABs } \text { min }^{-1} \mathrm{mg} \mathrm{protein}^{-1}\right)\end{array}$} \\
\hline Control & $0.27 \mathrm{cA}$ & $0.18 \mathrm{dC}$ & $0.22 \mathrm{cB}$ & 0.22 \\
\hline Sulfentrazone & $0.18 \mathrm{dC}$ & $0.25 \mathrm{cA}$ & $0.20 \mathrm{cB}$ & 0.21 \\
\hline Diclosulam & $0.50 \mathrm{bB}$ & $0.63 \mathrm{aA}$ & $0.25 \mathrm{bC}$ & 0.46 \\
\hline Imazethapyr & $0.57 \mathrm{aB}$ & $0.54 \mathrm{bC}$ & $0.61 \mathrm{aA}$ & 0.57 \\
\hline Mean & 0.38 & 0.41 & 0.32 & \\
\hline
\end{tabular}

Means followed by distinct letters differ in line (upper case) and column (lowercase) by Tukey test at $5 \%$ probability. 
which are genetically programmed but highly influenced by external factors.

In this way, the phenomena exposed and discussed previously are supported by the correlation of the variables (Figure 1). The characteristic SDM presented a positive correlation with SL, since the accumulation of dry mass varies according to the plant size, because this process is governed by growth and stretch of cells.

For GSI, there was a high magnitude positive correlation with GER due to the fact that the first factor considers the number of seeds germinated per day. Consequently, if the index measured daily is higher, the germination process will be greater due the intensity of this phenomenon. Miranda et al. (2015) evaluating the germination

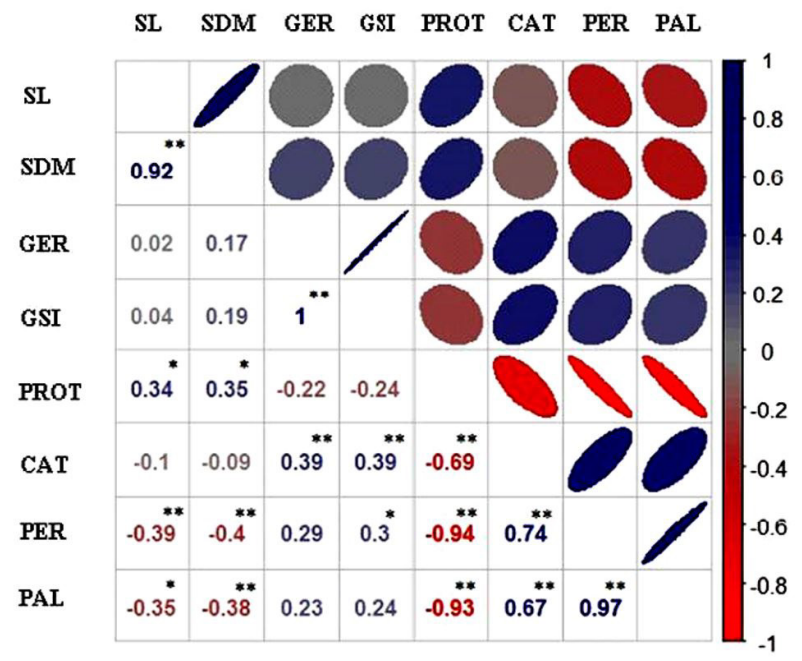

Figure 1. Pearson correlation for seedling length (SL), seedling dry mass (SDM), germination (GER), germination speed index (GSI), protein (PROT), catalase (CAT), peroxidase (PER) and phenylalanine ammonia-lyase (PAL) as a function of the residual effect of pre-emergent herbicides on different snap bean genotypes. ${ }^{* *}$ Significative a $1 \%$; *Significative a $5 \%$; Circles of blue staining, inclined to the right (positive correlation); Circles of red staining, inclined to the left (negative correlation); Circles of neutral staining, with zero inclination (absence of correlation). and vigor of lettuce seeds identified a positive correlation between the GER and GSI, a similar pattern found for snap bean submitted to the conditions established in the present study.

The interaction among the morphological and biochemical variables showed a positive correlation between the protein levels with SL and SDM. This performance can be justified by the fact that the protein is one of the main components of the cell wall and, therefore, with the increase of expansion and division of cells occurs an increase in protein levels (Taiz and Zeiger, 2013).

Regarding the enzymatic performance, there was a positive correlation among CAT and PER as well as of this group with the some morphological variables (Figure 1). The enzyme CAT presented a positive correlation with GER and GSI, while the PER showed only with GSI. The positive correlation between the enzymatic complex and part of the morphological variables may be related to the plant defense process, because when the seed is submitted to stressful conditions these enzymes act against the free radicals that cause phytotoxicity. Thus, in combating oxidative stress the enzymatic activity of defense allows, even under stress conditions, the seeds to activate and initiate the germination process.

This activation of the plant defense mechanism can be supported by the negative correlation between the CAT, PER and PAL enzymes with the values of PROT and also between PER and PAL with SL and SDM (Figure 1). This phenomena can be explained by the activity of the secondary metabolism (SM), because when this process begins it starts a competition for photoassimilates with the primary metabolism (PM), therefore, the largest SM activity results in a metabolic loss mainly by the use of erythro-4-phosphate substrates (pentose cycle) or phosphoenolpyruvate of glycolysis (route of phenylpropanoids). The last one, is an important route of plant defense and can partially redirect to SM the substrates used in plant growth (Mazaro et al., 2009). 
Moreover, with the activation of the defense mechanism, a transient change occurs in the ionic permeability of the plasmatic membrane, stimulating the entrance of $\mathrm{Ca}^{+2}$ and $\mathrm{H}^{+}$and output of $\mathrm{K}^{+}$and $\mathrm{Cl}^{-}$in cell, providing an increase of $\mathrm{Ca}^{+2}$ in the cytosol, which generates an oxidative explosion and activation of nitric oxide synthase, stimulating the production of ethylene (Taiz and Zeiger, 2013).

According to the same authors, there is an increase in the activity of enzymes related to oxidative stress and formation of antioxidant agents, in general phenolic compounds, formed mainly by the chiquimic acid pathway, with PAL being the principal enzyme of this metabolic route.

\section{Conclusions}

Even at a residual dose, the herbicides sulfentrazone, diclosulam and imazetapyr induced phytotoxicity in the initial development of snap bean seedlings.

The cultivar Macarrão Trepador showed lower tolerance to the residual effect of the pre-emergent herbicides, due the low enzyme activity related to the plant resistant and, consequently, higher protein levels.

\section{Acknowledgements}

The authors are grateful to the CAPES (Coordination for the Improvement of Higher Education Personnel), CNPq (Brazilian National Council for Scientific and Technological Development) and Araucária Foundation for financial support.

\section{References}

Anderson, M.D.; Prasad, T.K.; Stewart, C.R. Changes in isozyme profiles of catalase, peroxidase, and glutathione reductase during acclimation to chilling in mesocotyls of mayze seedlings. Plant Physiology, v.109, p.1247-1257, 1995.

Andres, A.; Freitas, G.D.; Concenço, G.; Melo, P.T.B.S.; Ferreira, F.A. Desempenho do cultivar de arroz BRS pelota e controle de capim-arroz (Echinochloa spp.) submetidos a quatro épocas de entrada d'água após aplicação de doses reduzidas de herbicidas. Planta Daninha, v.25, n.4, p.859867, 2007.

Blanco, F.M.G.; Velini, E.D.; Batista Filho, A. Persistência do herbicida sulfentrazone em solo cultivado com cana-de-açúcar. Bragantia, v.69, v.1, p.71-75, 2010.

Bradford, M.M. A rapid and sensitive method for the quantification of microgram quantities of protein utilizing the principle of protein-dye binding. Analitycal Biochemistry, v.72, p.248254, 1976.

Brasil. Ministério da Agricultura, Pecuária e Abastecimento. Regras para análise de sementes. Brasília, DF: Mapa/ACS, 2009. 395p.

Dan, H.A.; Dan, L.G.M.; Barroso, A.L.L.; Procópio, S.O.; Oliveira, J.R.; Silva, A.G.; et al. Residual activity of herbicides used in soybean agriculture on grain sorghum crop succession. Planta Daninha, v.28, p.1087-1095, 2010. Número especial.

Duart, V.M.; Duart, A.M.; Tramontin, M.T.; Spannemberg, R.; Garbuio, F.J. Controle de plantas daninhas em pré emergência em sistema de semeadura de arroz em solo seco. Revista Técnico Científica do IFSC, v.1, n.5, p.49, 2013.

Kuhn, O.J. Indução de resistência em feijoeiro (Phaseolus vulgaris) por acibenzolar-S-metil e Bacillus cereus: aspectos fisiológicos, bioquímicos e parâmetros de crescimento e produção. 2007. 140 f. Tese (Doutorado em Agronomia) - Escola Superior de Agricultura "Luiz de Queiroz", Universidade de São Paulo, Piracicaba, 2007.

Lusso, M.F.G.; Pascholati, S.F. Activity and isoenzymatic pattern of soluble peroxidases in maize tissues after mechanical injury or fungal inoculation. Summa Phytopathologica, v.25, n.3, p.244-249, 1999. 
Maguire, J.D. Speed of germination-aid in selection and evaluation for seedling emergence and vigor. Crop Science, v.2, n.2, p.176-177, 1962.

Mancuso, M.A.C.; Aires, B.C.; Negrisoli, E.; Corrêa, M.R.; Soratto, R.P. Seletividade e eficiência de herbicidas no controle de plantas daninhas na cultura do feijão-caupi. Revista Ceres, v.63, p.25-32, 2016.

Mazaro, S.M.; Wagner Junior, A.; Santos, I.; Citadin, I.; Possenti, J.; Gouvea, A. Controle do tombamento de plântulas de beterraba e tomate pelo tratamento de sementes com quitosana. Pesquisa Agropecuária Brasileira, v.44, n.11, p.1424-1430, 2009.

Miranda, C.A.S.F.; Cardoso, M.G.; Carvalho, M.L.M.; Machado, S.M.F.; Andrade, M.A.; Oliveira, C.M. Análise comparativa do potencial alelopático do óleo essencial de Thymus vulgaris e seu constituinte majoritário na germinação e vigor de sementes de alface (Lactuca sativa L.). E-xacta, v.8, n.2, p.45-53, 2015.

Oliveira Junior, R.S.; Constantin, J.; Inoue, M.H. Mecanismos de Ação de Herbicidas. Biologia e Manejo de Plantas Daninhas, 2011.

Pereira, J.W.; Melo Filho, P.A.; Albuquerque, M.B.; Nogueira, R.M.; Santos, R.C. Mudanças bioquímicas em genótipos de amendoim submetidos a déficit hídrico moderado. Revista ciência agronômica, v.43, n.4, p.766-773, 2012.

Pinto, J.J.O.; Noldin, J.A.; Rosenthal, M.D.; Pinho, C.F.; Rossi, F.; Machado, A.; et al. Atividade residual de (imazethapyr+ imazapic) sobre azevém anual (Lolium multiflorum), semeado em sucessão ao arroz irrigado, sistema Clearfield ${ }^{\circledR}$. Planta Daninha, v.27, n.3, p.609-619, 2009.

Raimondi, M.A.; Oliveira Junior, R.S.; Constantin, J.; Biffe, D.F.; Arantes, J.G.Z.; Franchini, L.H.; et al. Atividade residual de herbicidas aplicados ao solo em relação ao controle de quatro espécies de amaranthus. Planta Daninha, v.28, p.1073$1085,2010$.

Taiz, L.; Zeiger, E. Fisiologia vegetal. Porto Alegre: Artmed, 2013. p. 918.

Trevisan, E.; Belo, A.F.; Pires, F.R.; Bonomo, R.; Viana, D.G.; Egreja Filho, F.B. Influência da matéria orgânica na fitorremediação de solo contaminado com sulfentrazone. Revista Brasileira de Herbicidas, v.15, p.371-379, 2016.

Walperes, K.C.; Reis, M.R.; Carneiro, G.D.O.P.; Rocha, B.H.; Carvalho, R.D.; Melo, C.A.D.; Gonçalves, C.G. Residual de metribuzin no solo sobre o crescimento de alho, cebola e feijão. Revista Brasileira de Herbicidas, v.14, n.1, p.64-72, 2015.

Yassumoto, Y.; Osajima, J.A.; Takashima, K. Efeitos de oxidantes e sais inorgânicos na degradação fotocatalítica do herbicida imazetapir mediada por dióxido de titânio. Eclética Química, v.32, n.1, p.27-32, 2007.

Zobiole, L.H.S.; Oliveira Junior, R.S.; Tormena, C.A.; Constantin, J.; Cavalieri, S.D.; Alonso, D.G.; et al. Effect of soil compaction and sulfentrazone on soybean under two soil moisture conditions. Planta Daninha, v.25, n.3, p.537-545, 2007. 